\title{
Winter Cold Damage to Bitterbrush Related to Spring Sheep Grazing
}

\author{
CHARLES H. JENSEN AND PHILIP J. URNESS
}

\begin{abstract}
Sub-freezing winter cold occasionally causes extensive damage to rangeland shrubs. Bitterbrush (Purshia tridentata) was damaged in northern Utah during the winter of 1972-1973. The damage appeared to be largely independent of spring grazing by domestic sheep. Managers should recognize and separate the influence of such damage from grazing influences to properly assign stocking levels. Improper interpretation of reduced browse plant production or condition may lead to unnecessary reductions in animal populations.
\end{abstract}

Sub-zero winter cold has injured or caused death of woody plants in temperate regions. Damage appears to occur in two ways. One, a sudden drop in temperature following prolonged periods of mild fall weather desiccates cells of plants that are not frost-hardened. Damage of this type becomes severe when temperatures reach the homogeneous nucleation temperature of water (Burke et al. 1976), that temperature at which supercooled, pure water turns from liquid to a solid, approximately $-40^{\circ} \mathrm{C}\left(-40^{\circ} \mathrm{F}\right)$. A sudden drop in temperature following mild weather caused death and injury to fourwing saltbush (Atriplex canescens) in Utah plantations (Van Epps 1975; McArthur 1977). Sugar maple (Acer saccharum) failed to leaf out in New York state after the winter of 1933-34 and abnormally cold temperature over a long period of time was thought to be responsible (Cope 1935). In California, the exposed tops of two species of conifers were killed in consequence of a sudden temperature drop in January 1944 (Wagener 1949). Similar conditions caused death of ponderosa pine (Pinus ponderosa) in a northern Idaho plantation, and ecotypes from warmer climates were injured most (Daubenmire 1957). Stickney (1965) postulated that the distribution of snowbush ceanothus (Ceanothus velutinus) was dependent upon an insulating snow cover which protected it from cold temperatures. While rangeland and forest plants have been injured by cold temperatures, reports of such damage are not numerous. Most research has been done on horticultural and ornamental cultivars and the mechanism of cold injury.

A second way plants are injured by cold is the freezing of green foliage in the spring after woody plants have broken dormancy. Smith et al. (1965) reported extensive damage to bitterbrush (Purshia tridentata) by such conditions. The mechanism of both types of injury and resistance to injury was

The authors are wildlife biologist, Utah Division of Wildlife Resources, Department of Range Science, Utah State University, Logan 84322; and Federal Aid project leader, Utah Division of Wildlife Resources and associate professor, Department of Range Science Utah State University, Logan.

This study is a contribution of Utah Division of Wildlife Resources, Federal Aid Project W-105-R

Manuscript received April 2J, 1978. thoroughly discussed by Wiser (1970a, 1970b). This paper reports the extent of winter injury to bitterbrush plants that were not frost-hardened as an adjunct to a grazing study involving domestic sheep and free-ranging elk.

\section{Methods}

A study of ten grazing treatments was initiated in 1971 at Hardware Ranch, Cache County, Utah. Eight pastures were grazed by domestic sheep during four different springtime periods and at two intensities within each period. Those pastures were open to elk use in winter. Another treatment was open to elk use alone and a tenth treatment excluded all ungulate use. Permanent transect lines were established in each treatment. Additional transect lines were established in two areas below the study pastures and parallel to the bottom of a draw, one on a northerly exposure and one on a southerly exposure. After the unusually cold temperatures in December 1972 and January 1973, and the apparent, subsequent damage to bitterbrush plants, 50 plants which intercepted the transect lines in each treatment were assessed for damage and condition in June 1973. Ocular estimates of the percentage of live and dead branches were made and divided into three categories: (1) those branches with dead but intact buds that had dried during the 1972-1973 winter; (2) small dead branches devoid of buds, but retaining some bark-these died prior to the 1972-1973 winter; and (3) live branches on which over-wintering leaf buds were produced in 1972. Seeds were counted on twenty bitterbush plants in each treatment which had been tagged in 1971 for annual observations.

Official Weather Bureau records were kept at the Hardware Ranch Headquarters, about $1 \mathrm{~km}$ from the study pastures (U.S. Dep. of Commerce 1972 and 1973).

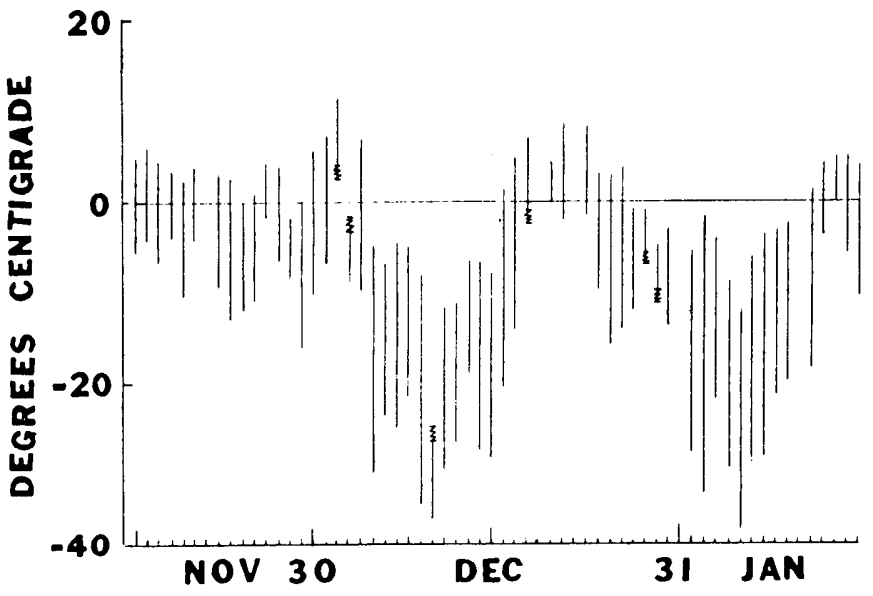

Fig. 1. Daily temperature ranges at the Hardware Ranch Climatological Station from November 15, 1972, to January 15, 1973 (U.S. Dep. Commerce Climatological Records, Utah Vol. 74 and 75, 1972, 1973. 
Table 1. Percentages of live and dead material in crowns of bitterbrush plants within nine different grazing treatments (eight by domestic sheep and elk and one by elk alone) at Hardware Ranch, 1973. ${ }^{1}$

\begin{tabular}{|c|c|c|c|c|c|c|c|c|}
\hline \multirow[b]{3}{*}{$\begin{array}{l}\text { Inclusive } \\
\text { Grazing } \\
\text { dates }\end{array}$} & \multicolumn{8}{|c|}{ Intensity of sheep use } \\
\hline & \multicolumn{4}{|c|}{$35 \%$ Utilization } & \multicolumn{4}{|c|}{$70 \%$ Utilization } \\
\hline & $\begin{array}{c}\% \\
\text { Live }\end{array}$ & $\begin{array}{c}\% \\
\begin{array}{c}\% \\
\text { Dead } \\
\text { before } \\
1973\end{array}\end{array}$ & $\begin{array}{c}\% \\
\text { Dead } \\
\text { in } \\
1973\end{array}$ & $\begin{array}{c}\% \text { of } \\
\text { Live } \\
\text { that died } \\
\text { in } 1972-1973^{2}\end{array}$ & $\begin{array}{c}\% \\
\text { Live }\end{array}$ & $\begin{array}{c}\% \\
\text { Dead } \\
\text { before } \\
1973\end{array}$ & $\begin{array}{c}\% \\
\text { Dead } \\
\text { in } \\
1973\end{array}$ & $\begin{array}{c}\% \text { of } \\
\text { Live that } \\
\text { died in } \\
1972-1973^{2}\end{array}$ \\
\hline May 4-May 24 & 49 & 39 & 12 & 20 & 59 & 30 & 11 & 16 \\
\hline May 24-June 9 & 57 & 31 & 12 & 17 & 36 & 45 & 19 & 34 \\
\hline June 9 -June 24 & 48 & 30 & 22 & 31 & 53 & 39 & 8 & 13 \\
\hline May 4 - June 24 & 52 & 34 & 14 & 21 & 55 & 25 & 20 & 27 \\
\hline \multirow[t]{3}{*}{ Means } & 52 & 34 & 14 & 21 & 51 & 35 & 14 & 22 \\
\hline & \multicolumn{8}{|c|}{ Elk Use Only } \\
\hline & 58 & 20 & 21 & 27 & & & & \\
\hline
\end{tabular}

Data were not collected from the nonuse treatment.

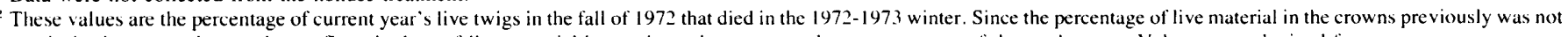
precisely the same, those values reflect the loss of live material better than when expressed as a percentage of the total crown. Values were obtained from:

$$
\text { live }+\% \text { dead in } 73.3 .7100
$$

\section{Results and Discussion}

Mean minimum temperatures for November and December 1972 and January 1973 were $-8^{\circ} \mathrm{C}\left(18^{\circ} \mathrm{F}\right),-18^{\circ} \mathrm{C}\left(0^{\circ} \mathrm{F}\right)$ and $-19^{\circ} \mathrm{C}\left(-1^{\circ} \mathrm{F}\right)$, respectively. A sudden drop in temperature on December 5 , preceded by comparatively warm temperatures, probably did not allow for adequate cold hardening of bitterbrush (Fig. 1).

Extreme cold temperatures of $-37^{\circ} \mathrm{C}\left(-35^{\circ} \mathrm{F}\right)$ and $-38^{\circ} \mathrm{C}$ $\left(-37^{\circ} \mathrm{F}\right)$ occurred on December 10 and January 5 , respectively. Those temperatures were near the "homogeneous nucleation temperature of water" (Burke et al. 1976) and they also approach the temperature where some plants have shown permanent damage (George et al. 1977).

In consequence of the winter cold, extensive damage was observed in spring 1973 on numerous ornamental and horticultural varieties throughout northern Utah. Varieties of the rose family, particularly peaches, were damaged most. The valuable rangeland shrub, bitterbrush, was also extensively damaged in the vicinity of Hardware Ranch. Many twigs were killed in December 1972 as indicated by two lines of evidence. First, browse utilization by elk was less than in the previous winter $(6 \%$ compared to $10 \%$ ). Elk usually browse shrubs in this area in late winter. At that time in 1973, twigs were dead and dry and consequently unattractive and unbrowsed. Second, many of the buds and overwintering leaves were dead and had turned brown

Table 2. Reduction in bitterbrush seed production as affected by winter cold in ten sheep-grazing treatments at Hardware Ranch from 1972 to 1973.

\begin{tabular}{lrrr}
\hline \hline Grazing intensity & \multicolumn{2}{c}{ Seed number/plant } & \\
\cline { 2 - 3 } and time of use & 1972 & 1973 & \% Decrease \\
\hline 35\% May 4 to May 24 & 387 & 70 & 82 \\
35\% May 24 to June 9 & 749 & 120 & 84 \\
35\% June 9 to June 24 & 46 & 6 & 87 \\
35\% May 4 to June 24 & 383 & 50 & 87 \\
$70 \%$ May 4 to May 24 & 268 & 114 & 57 \\
$70 \%$ May 24 to June 9 & 64 & 9 & 86 \\
$70 \%$ June 9 to June 24 & 82 & 1 & 99 \\
$70 \%$ May 4 to June 24 & 208 & 6 & 97 \\
Elk use only & 369 & 100 & 73 \\
Nonuse & 1834 & 321 & 88 \\
Mean (-Nonuse) & 284 & 53 & 81 \\
\hline
\end{tabular}

by mid April. Some of the twigs, where buds had been killed, developed adventitious buds which succumbed after several weeks of chlorotic growth. Cracked and damaged bark was evident on dead and drying twigs.

Injury to bitterbrush foliage appeared to be independent of sheep grazing intensity or time of use. Tops of some plants were killed, but most damaged plants subsequently sprouted from the crowns. The treatment open to elk use only was near a ridge top and suffered $21 \%$ loss of live material, essentially comparable to the loss incurred under both intensities of sheep use (Table 1). The greatest loss was on a southeast exposure near the bottom of a gully, where $66 \%$ of the live current growth was killed, an area ungrazed by sheep. On an opposing northwest exposure at a comparable distance from the drainage channel where plants were partially covered by snow, $32 \%$ of the live material in the crowns died in the winter of 1972-1973. Except for the northwest side of the shrubs, where some snow persisted in December, shrubs on the southeast slope were completely exposed. Branches that were protected by snow survived; most of these were flexible and matted near ground level beneath the first snowfall.

Reductions in seed production suggested little influence of grazing when compared to the effects of cold (Table 2). For the nine grazed pastures, seed production decreases averaged $81 \%$, less than complete protection and slightly greater than elk use alone. There was some indication that heavy grazing in midMay the preceding year reduced the severity of cold damage while heavy grazing in late June magnified it. The lower numbers of seed in 1973 produced per plant in the later grazing periods and at the heavy intensity of 1972 represent a reduction caused by utilization of growing twigs in 1972. Those reductions are real; the cold damage is simply added to it in 1973.

In conclusion, cold temperatures caused severe injury to crowns of bitterbrush at Hardware Ranch. Injury to other plant species has been observed in other areas. Conditions of comparatively warm weather in fall and early winter followed by sudden extreme drops in temperature were throught to be responsible for the damage. The fact that cold injury is responsible for the damage is important to big game managers. Failure to recognize the true cause of shrub losses could lead to the erroneous conclusion that ranges are over-stocked, and subsequent ill-advised range management programs. 


\section{Literature Cited}

Burke, M.J., L.V. Gusta, H.A. Quamme, C.J. Wiser, and P.H. Li. 1976. Freezing injury in plants. Annu. Rev. Plant Physiol. 27:507-528.

Cope, J.A. 1935. Winter injury to hardwoods in 1933-1934. J. Forestry 33:939-940.

Daubenmire, R. 1957. Injury to plants from rapidly dropping temperatures in northern Idaho. J. Forestry 55:581-585.

George, M.F., S.G. Hong, and M.J. Burke. 1977. Cold hardiness and deep supercooling of hardwoods: its occurrence in provenance collections of red oak, yellow birch, black walnut, and black cherry. Ecology 58:674-680.

McArthur, E.D. 1977. Environmental induced changes of sex expression in Atriplex canescens. Heredity 38:97-103.
Smith, R.S., Jr., R.F. Scharpf, and E.R. Schneegas. 1965. Frost injury to bitterbrush in eastern California. U.S. Forest Serv. Res. Note PSW-82. 4 p. Stickney, P.F. 1965. Note on winter kill of Ceanothus velutinus. Proc. Montana Academy of Sci. 25:52-57.

U.S. Department of Commerce. 1972, 1973. Climatological data. Utah Vol. $74,75$.

Van Epps, G. 1975. Winter injury to fourwing saltbush. J. Range Manage. 28:157-159.

Wagener, W.W. 1949. Top drying of conifers from sudden cold. J. Forestry 47:49-53.

Wiser, C.J. 1970a. Cold resistance and injury in woody plants. Science 169:1269-1278.

Wiser, C.J. 1970b. Cold resistance and acclimation in woody plants. Hort. Science 5:403-410. 